\title{
Kajian Pengelolaan Sampah Berdasarkan Daya Dukung dan Kapasitas Tampung Prasarana Persampahan Kota Depok
}

\author{
Study of Solid Waste Management Based on Carrying Capacity and \\ Storage Capacity of Waste Infrastructures in Depok City \\ Diana Paramita $^{1^{*}}$, Kukuh Murtilaksono $^{2} \&$ Manuwoto $^{1}$ \\ ${ }^{1}$ Program Studi Ilmu Perencanaan Wilayah, Sekolah Pascasarjana, Institut Pertanian Bogor, Kampus IPB \\ Dramaga, Bogor 16680, Indonesia; ${ }^{2}$ Departemen Ilmu Tanah dan Sumber Daya Lahan, Institut Pertanian \\ Bogor, Kampus IPB Dramaga, Bogor 16680, Indonesia; \\ "Penulis korespondensi. e-mail: diana.paramita0@gmail.com; \\ (Diterima: 28 Februari 2018; Disetujui: 22 Juni 2018)
}

\begin{abstract}
Depok City can only manage about $56.22 \%$ from total of 1,286 tons of its daily solid waste. The amount increases everyday that it becomes more concerning to apply solid waste management. The objective of this research is to analyze solid waste management based on the carrying capacity and the storage capacity of waste infrastructures in Depok City. Methods of this study were the suitability between supply and demand of domestic solid waste and the waste infrastructures, Integrated Risk Based Approach (IRBA) and literature study. This study shows that Depok City government has a good system in solid waste management but still needs to improve the quantity and capacity of the infrastructures. Garbage banks can reduce $20 \%$ of the inorganic waste and the Organic Waste Processing Unit (Unit Pengolahan Sampah Organik/UPS) has low index carrying capacity of 0.26, which can reduce $3.64 \%$ of organic waste. The IRBA shows that Cipayung landfill has moderate danger. The numbers of waste infrastructures required at each district in Depok City shall be equipped, so that the amount of waste disposed to Cipayung landfill can be reduced.
\end{abstract}

Keywords: carrying capacity, garbage bank, solid waste management, waste infrastructure capacity

\begin{abstract}
ABSTRAK
Kota Depok baru mampu mengelola sampah sekitar 56.22\% dari jumlah timbulan sampah sebanyak 1,286 ton setiap hari. Jumlah ini senantiasa meningkat setiap hari dan perlu mendapatkan perhatian. Oleh karena itu pengelolaan sampah harus diterapkan. Tujuan dari penelitian ini adalah untuk menganalisis pengelolaan sampah berdasarkan kemampuan daya dukung dan kapasitas tamping prasarana persampahan di Kota Depok. Metode yang digunakan adalah kesesuaian supply dan demand dari sampah rumah tangga yang dihasilkan dengan prasarana persampahan, Integrated Risk Based Approach (IRBA) dan studi pustaka. Hasil dari penelitian ini menunjukkan bahwa pemerintah Kota Depok telah memiliki sistem pengelolaan sampah yang baik namun perlu meningkatkan jumlah dan kapasitas prasarana persampahan. Pengelolaan sampah anorganik melalui bank sampah mengurangi 20\% timbulan sampah dan Unit Pengolahan Sampah Organik (UPS)memiliki indeks daya dukung rendah, yaitu sebesar 0.26 yang mampu mengurangi $3.64 \%$ sampah organik. Hasil IRBA Tempat Pemrosesan Akhir (TPA) menunjukkan TPA Cipayung memiliki tingkat evaluasi bahaya sedang. Jumlah prasarana persampahan di Kota Depok sangat kurang sehingga pemerintah Kota Depok perlu melengkapi kebutuhan prasarana di setiap kecamatan agar dapat mengurangi jumlah sampah yang dibuang ke TPA.
\end{abstract}

Kata kunci: bank sampah, daya dukung, kapasitas tampung, prasarana persampahan, pengelolaan sampah 


\section{PENDAHULUAN}

Seiring laju perekonomian yang meningkat, proporsi penduduk Indonesia yang tinggal di daerah perkotaan bertambah, dan telah menimbulkan fenomena urbanisasi yang menyebabkan beban wilayah perkotaan naik. Laju pertumbuhan penduduk perkotaan di Indonesia menunjukkan peningkatan yang pesat, pada periode 1971 hingga 1980 sebesar $4.6 \%$ per tahun dan meningkat mencapai $5.36 \%$ pada periode 1981 hingga 1990 dengan laju pertumbuhan penduduk perkotaan dua setengah kali laju pertumbuhan penduduk sebesar 1.97\% per tahun (Tjiptoherijanto, 1999). Dalam perkembangannya, saat ini megacity Jabodetabek yang merupakan kawasan megapolitan yang terdiri atas Daerah Khusus Ibukota Jakarta dan wilayah penyangganya, yaitu Bogor, Depok, Tangerang, dan Bekasi adalah wilayah perkotaan terbesar kedua di Asia setelah Kota Metropolitan Tokyo dengan ukuran wilayah $0.35 \%$ dari luas Negara Indonesia, dihuni oleh $11.3 \%$ penduduk Indonesia dengan laju pertumbuhan penduduk periode 2000 hingga 2010 sebesar $2.62 \%$ sehingga memberikan dampak lingkungan dan masalah sosial (Pravitasari et al., 2016). Salah satu permasalahan utama yang disebabkan oleh urbanisasi adalah meningkatnya jumlah sampah di perkotaan yang dapat mengakibatkan degradasi lingkungan perkotaan dan menimbulkan masalah kesehatan (Joshi \& Ahmed, 2016). Pada daerah perkotaan di negara berkembang, terutama pada kota dengan tingkat urbanisasi yang tinggi, persampahan menjadi salah satu masalah yang perlu mendapatkan perhatian khusus. Pertambahan penduduk yang cepat perlu diimbangi dengan kapasitas pelayanan pengelolaan sampah sesuai kebutuhan agar tidak bertumpuk di jalan dan saluran air yang dapat menyebabkan banjir, meningkatkan jumlah serangga, dan menjadi sarana berkembangnya penyakit. Sementara penanganan sampah oleh Pemerintah umumnya hanya berupa pembuangan dan penimbunan pada lokasi tertentu atau dibakar sehingga dapat

4 sampahmasyarakat.com 21 Maret 2016 menyebabkan polusi air dan udara (Zurbrügg \& Schertenleib, 1998).

Permasalahan sampah umum dihadapi pada daerah perkotaan di negara Asia Tenggara, seiring meningkatnya jumlah penduduk, diikuti oleh peningkatan pendapatan, perubahan pola konsumsi, pertumbuhan ekonomi, serta urbanisasi dan industrialisasi sehingga mengakibatkan meningkatnya potensi timbulan sampah perkapita dan beragamnya jenis sampah yang dihasilkan (Nguyen \& Schnitzer, 2009). Negara Indonesia juga mengalami masalah persampahan, sebagaimana data Kementerian Lingkungan Hidup dan Kehutanan dalam Dialog Penanganan Sampah Plastik pada rangkaian Peringatan Hari Lingkungan Hidup Sedunia di Jakarta tanggal 10 Juni 2015 bahwa jumlah sampah yang dihasilkan sebanyak 175,000 ton per hari atau 64 juta ton per tahun. Dalam dialog ini juga disampaikan hasil studi tahun 2012 bahwa pola pengelolaan sampah di Indonesia adalah diangkut dan ditimbun di TPA (69\%), dikubur (10\%), dikompos dan didaurulang (7\%), dibakar (5\%), dan tidak dikelola (7\%), dan lebih dari 90\% kabupaten/kota di Indonesia masih menggunakan sistem penanganan sampah secara open dumping atau bahkan dibakar (KemenLHK, 2015). Sementara itu berdasarkan data Badan Pusat Statistik, persentase sampah yang dipilah mengalami penurunan, yaitu dari sebesar $23.69 \%$ pada tahun 2013, menjadi sebesar $18.84 \%$ pada tahun 2014 atau penurunan sebesar $-4.85 \%$ (BPS, 2017). Data ini dapat memberikan gambaran bahwa masyarakat Indonesia belum konsisten dalam melakukan pengolahan sampah pada umumnya, khususnya pemilahan sampah.

Pulau Jawa menghasilkan sampah terbanyak di Indonesia, yaitu 21.2 juta ton/tahun yang didominasi oleh sampah rumah tangga $(44.5 \%)$, dengan rata-rata sampah per kapita $0.61 \mathrm{~kg} / \mathrm{hari} / \mathrm{jiwa}{ }^{4}$. Kota Depok sebagai salah satu kota baru di pulau Jawa telah mengembangkan sistem persampahan perkotaannya. 
Berdasarkan data Dinas Lingkungan Hidup dan Kebersihan Kota Depok tahun 2016, jumlah sampah yang dikelola sebesar 57.2\% dari 1,286 ton per hari melalui pemilahan sampah, pengomposan, dan membuang sisa sampah ke Tempat Pemrosesan Akhir (TPA) Cipayung (Pemkot Depok, 2016). Moeinaddini et al. (2013) dalam Othman et al. (2013) menunjukkan pengelolaan sampah yang efektif adalah melalui sistem yang meliputi pengurangan (reduce), penggunaan kembali (reuse), daur ulang/ pemanfaatan energi dari sampah (recycle), dan insinerasi. Langkah akhir dalam sistem ini adalah melakukan sanitary landfill pada sisa sampah residu yang sudah tidak dapat diolah kembali. Atas dasar hal tersebut, perlu dilakukan penelitian penyelenggaraan penanganan sampah di Kota Depok dengan melakukan analisis daya dukung dan kapasitas tampung sarana dan prasarana persampahan serta Tempat Pemrosesan Akhir (TPA) Cipayung Kota Depok. Tujuan dari penelitian ini adalah untuk menganalisis pengelolaan sampah berdasarkan kemampuan daya dukung dan kapasitas tampung prasarana persampahan di Kota Depok.

\section{METODOLOGI}

Penelitian dilakukan di Kota Depok Provinsi Jawa Barat, terletak pada koordinat
6018'30" hingga 6028'00" Lintang Selatan dan $106^{0} 42^{\prime} 30^{\prime}$ " hingga $106^{0} 55^{\prime} 30^{\prime \prime}$ Bujur Timur, dengan luas 20,029 hektar, meliputi 11 kecamatan, yaitu kecamatan Beji, Bojongsari, Cilodong, Cimanggis, Cinere, Cipayung, Limo, Pancoran Mas, Sawangan, Sukmajaya, dan Tapos (RTRW Kota Depok, 2015). Penelitian dilaksanakan mulai bulan Juli 2017 sampai dengan bulan Desember 2017.

Alat yang digunakan untuk mendukung penelitian ini terdiri dari seperangkat komputer dengan perangkat lunak (software) Quantum GIS 14, Microsoft Word, Microsoft Excel, dan kamera. Data yang digunakan dalam penelitian ini terdiri atas data primer, yaitu data kondisi TPA, penanganan sampah eksisting, data pengelolaan Bank Sampah, serta hasil wawancara dengan narasumber terpilih serta data sekunder, yaitu Peta RTRW, Peraturan Daerah Kota Depok No. 5 Tahun 2014 tentang Pengelolaan Sampah, data jumlah penduduk Tahun 2016, data timbulan sampah Tahun 2016, data kondisi TPA Tahun 2016, data sarana dan prasarana TPA, data jumlah bank sampah Tahun 2016, data sampah dapat dikelola Tahun 2016, serta data lokasi dan kapasitas UPS Tahun 2016. Penggunaan data Tahun 2016 adalah data yang telah dipublikasi secara resmi oleh Pemerintah Kota Depok. Lokasi Kota Depok dapat dilihat pada Gambar 1.

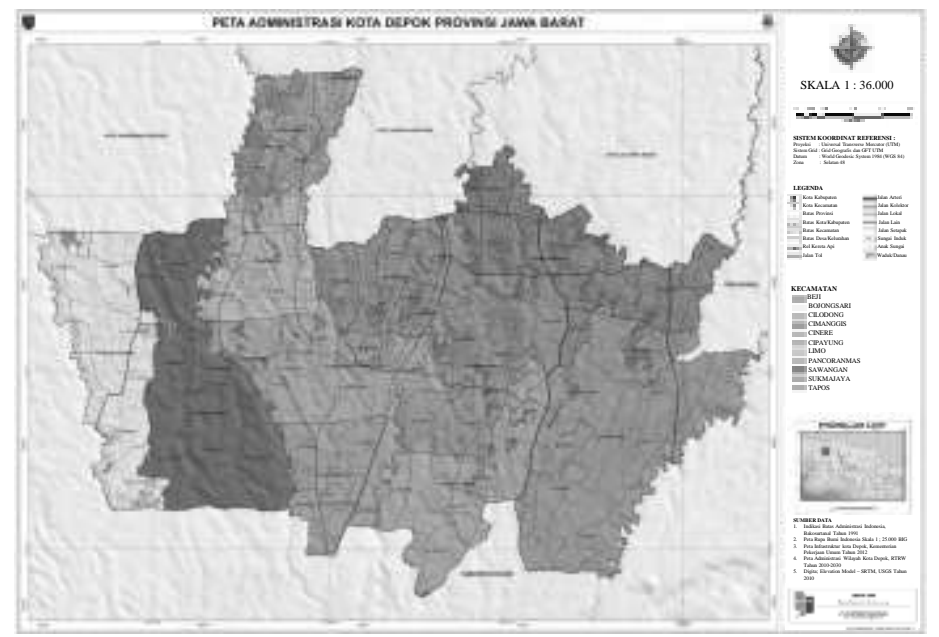

Gambar 1. Peta lokasi penelitian

Sumber: RTRW Kota Depok Tahun 2012-2032 


\section{Prosedur Analisis Data Analisis Penanganan Sampah Saat Ini}

Analisis penanganan sampah saat ini dilakukan dengan menginput data lokasi dan kapasitas UPS serta data jumlah bank sampah yang terdapat pada setiap kecamatan dengan menggunakan software Quantum GIS. Setelah itu membandingkan potensi timbulan sampah organik dengan kapasitas UPS dalam mengolah sampah organik dan potensi timbulan sampah anorganik yang dapat didaur ulang dengan kemampuan bank sampah menangani sampah anorganik yang dapat didaur ulang yang didukung data hasil wawancara yang dianalisis dengan metode kualitatif model data.

\section{Analisis Daya Dukung dan Kapasitas Tampung UPS}

Analisis daya dukung dan kapasitas tampung UPS dilakukan dengan menggunakan analisis kesesuaian supply dan demand antara potensi timbulan sampah organik yang dihasilkan oleh setiap kecamatan dengan lokasi dan kapasitas UPS yang terdapat pada setiap kecamatan di Kota Depok. Pendekatan ini dilakukan untuk mengetahui ketersediaan prasarana UPS dalam mengelola sampah organik yang dihasilkan oleh warga Kota Depok pada setiap kecamatan.

Timbulan sampah dan potensi timbulan organik diperoleh dari data DLHK. Rata-rata sampah yang dihasilkan oleh setiap warga Kota Depok sebesar $0.63 \%$ dengan persentase timbulan sampah organik yang dihasilkan sebesar 55\% dari jumlah sampah yang dihasilkan (Pemkot Depok, 2016). Perhitungan ini dapat dirumuskan sebagai berikut:

Potensi Timbulan Sampah Organik $=$
$55 \%$ x Timbulan Sampah Timbulan Sampah =

$0,63 \mathrm{~kg} \times$ Jumlah Penduduk

Khairunisa (2011) melakukan penelitian untuk mengetahui daya dukung Tempat Pengolahan Sampah Sementara (TPS) dengan cara menganalisis perbandingan potensi sampah terolah dan potensi mesin pencacah dengan realisasi pemanfaatan potensi tersebut. Jika potensi yang dimiliki lebih kecil sama dengan potensi yang termanfaatkan, dapat disimpulkan TPS memiliki daya dukung lingkungan yang tinggi. Sementara jika potensi yang dimiliki lebih besar dari potensi yang termanfaatkan, dapat disimpulkan TPS memiliki daya dukung yang rendah. Indeks daya dukung lingkungan dihitung secara matematis dengan menggunakan rumus berikut:

Indeks Daya Dukung =

$\underline{\text { Potensi Termanfaatkan }}$

Potensi yang Dimiliki

Total kapasitas pengelolaan dibandingkan dengan total jumlah timbulan sampah dengan menghitung selisihnya menggunakan rumus berikut:

Selisih $=$ Total Kapasitas Pengelolaan - Total Timbulan Sampah

Jika selisih antara total kapasitas pengelolaan dengan total timbulan sampah lebih besar sama dengan 0, maka dapat diindikasikan bahwa daya dukung TPS belum terlampaui. Sebaliknya, jika selisih antara total kapasitas pengelolaan dengan total timbulan sampah lebih kecil sama dengan 0 maka dapat dindikasikan bahwa daya dukung TPS telah terlampaui.

\section{Analisis Daya Dukung dan Kapasitas Tampung TPA}

Kota Depok memiliki satu unit TPA yang terletak di kecamatan Cipayung untuk melayani pengolahan sampah yang dihasilkan oleh warga Kota Depok. Oleh karena itu perlu dilakukan penilaian terhadap daya dukung dan kapasitas tampung TPA Cipayung.

Dalam penelitian Kurian et al. (2005), kriteria penilaian yang dibangun untuk mengambil keputusan rehabilitasi TPA menggunakan pendekatan risiko kesehatan, dampak lingkungan, dan kepedulian warga sekitar TPA yang dianalisis dengan menggunakan indeks sensitivitas. Kriteria ini digunakan untuk mengetahui daya dukung dan 
kapasitas tampung TPA Cipayung melalui penilaian indeks risiko lingkungan TPA yang sebagaimana dalam Peraturan Menteri Pekerjaan Umum Nomor 03/PRT/M/2013 tentang Penyelenggaraan Prasarana dan Sarana Persampahan Dalam Penanganan Sampah Rumah Tangga dan Sampah Sejenis Sampah Rumah Tangga. dan dihitung dengan persamaan berikut:

$$
\mathrm{RI}=\sum_{\mathrm{i}=1}^{\mathrm{n}} \mathrm{WiSi}
$$

Keterangan:

Wi : Bobot dari parameter ke-i, rentang nilai 0 sampai 1000

$\mathrm{Si}$ : Indeks Sensitivitas parameter ke-i, rentang nilai 0 sampai 1

RI : Indeks Risiko, rentang nilai 0 sampai 1000

Indeks Risiko (Risk Index / RI) dapat digunakan untuk klasifikasi dari tempat penimbunan sampah untuk ditutup atau direhabilitasi. Nilai 0 mengindikasikan tidak atau kurang bahaya, nilai 1 mengindikasikan potensi bahaya tertinggi. Prioritas menurun dengan turunnya jumlah nilai. Nilai terendah mengindikasikan sensitivitas rendah dan dampak lingkungan kecil. Kriteria evaluasi tingkat bahaya berdasar nilai indeks risiko tempat penimbunan sampah dapat dilihat pada Tabel 1.

Tabel 1. Kriteria evaluasi tingkat bahaya berdasarkan nilai indeks risiko

\begin{tabular}{|c|c|c|}
\hline $\begin{array}{l}\text { Nilai } \\
\text { Indeks } \\
\text { Risiko } \\
(\mathrm{RI})\end{array}$ & $\begin{array}{l}\text { Evaluasi } \\
\text { Bahaya }\end{array}$ & Tindakan yang Disarankan \\
\hline$<300$ & Rendah & $\begin{array}{l}\text { TPA diteruskan dan } \\
\text { direhabilitasi menjadi lahan } \\
\text { urug terkendali. Lokasi ini } \\
\text { berpotensi } \\
\text { dikembangkan } \\
\text { lahan urug dalam } \\
\text { yang lama }\end{array}$ \\
\hline $\begin{array}{l}300- \\
600\end{array}$ & Sedang & $\begin{array}{l}\text { TPA diteruskan dan } \\
\text { direhabilitasi menjadi lahan } \\
\text { urug terkendali secara } \\
\text { bertahap }\end{array}$ \\
\hline $601-$ & Sangat & TPA harus segera ditutup \\
\hline 1000 & Tinggi & $\begin{array}{l}\text { karena mencemari } \\
\text { lingkungan atau masalah } \\
\text { sosial }\end{array}$ \\
\hline
\end{tabular}

Sumber: Lampiran V PermenPU No 03/PRT/M/2013

\section{HASIL DAN PEMBAHASAN}

\section{Analisis Penanganan Sampah Saat Ini}

Pengelolaan sampah di Kota Depok merupakan tanggung jawab pemerintah Kota yang secara teknis dilakukan oleh Dinas Lingkungan Hidup dan Kebersihan (DLHK) sebagai unsur pelaksana teknis di bawah Walikota Depok yang berfungsi sebagai pelaksana pelayanan kebersihan (operator) dan pengatur/pengendali (regulator) kebersihan. Kepala DLHK menjalankan fungsi sebagai penanggung jawab pengelolaan sampah, yang secara teknis beroperasi di bawah koordinasi Bidang Kebersihan yang dibantu oleh Koordinator Kecamatan dan staf Bidang Kebersihan. Tingkat layanan pengelolaan sampah oleh DLHK pada tahun 2016 adalah sebesar $56.22 \%$ dari jumlah timbulan sampah sebanyak 1,286 ton per hari. Timbulan sampah yang tidak dikelola oleh DLHK dikelola secara mandiri oleh masyarakat dan dipilah oleh pengepul/lapak.

Persentase komposisi sampah yang paling besar di Kota Depok adalah sampah organik sebanyak $55 \%$ yang berpeluang untuk didaur ulang menjadi kompos. Komposisi sampah lainnya adalah sampah anorganik yang dapat didaur ulang sebesar $20 \%$, kain dan tekstil sebesar $8 \%$, karet dan kulit sebesar 2\%, dan sampah selain kategori yang ada sebesar $15 \%$. Kategori kain dan tekstil, karet dan kulit, serta sampah lain belum memiliki peluang untuk dikelola sehingga termasuk ke dalam residu yang penanganan akhirnya berupa penimbunan di TPA Cipayung.

Sejak diberlakukannya Peraturan Daerah Kota Depok Nomor 05 Tahun 2014 tentang Pengelolaan Sampah dan diperkuat dengan Peraturan Walikota Depok Nomor 46 Tahun 2016 tentang Pedoman Pengelolaan Sampah yang mengamanatkan setiap orang untuk mengurangi dan menangani sampah, masyarakat Kota Depok di bawah koordinasi DLHK melakukan partisipasi pengurangan sampah yang meliputi pembatasan timbulan sampah, pendauran ulang sampah, dan atau pemanfaatan kembali sampah. Gerakan 
memilah sampah disosialisasikan oleh DLHK Kota Depok pada tingkat kelurahan melalui kegiatan kemasyarakatan agar penyampaian program dapat dilakukan secara intensif kepada masyarakat. Kegiatan yang dilakukan adalah mewadahi setiap jenis timbulan sampah ke dalam tiga pewadahan karena penanganan pewadahan dan pemilahan setiap jenis sampah berbeda. Sampah organik dikumpulkan oleh setiap rumah tangga menggunakan wadah ember bertutup yang kemudian ditampung oleh petugas ke dalam satu ember besar untuk dibawa dan diolah UPS. Sampah anorganik dipilah menjadi beberapa kategori seperti kertas, plastik, logam, dan kaca untuk disetorkan ke bank sampah tingkat RT/RW yang selanjutnya dikirimkan ke Bank Sampah Induk atau pengepul. Bank Sampah Induk yang terdapat di Kota Depok sebanyak tiga unit yang terdapat di kecamatan Sukmajaya, kecamatan Beji, dan kecamatan Pancoran Mas. Tugas dari bank sampah induk adalah melayani pengumpulan dan distribusi sampah dari setiap unit bank sampah ke industri serta membantu DLHK dalam melakukan sosialisasi pemilahan sampah di tingkat rumah tangga dan membina pengelolaan bank sampah. Sampah residu serta bahan berbahaya dan beracun (B3) dimasukkan ke dalam wadah berupa kantong plastik hitam, kemudian dikumpulkan ke titik kumpul untuk selanjutnya diangkut menuju lokasi TPA.

Bank sampah mendukung program pemerintah dengan mengubah perilaku masyarakat untuk memilah sampah organik dan anorganik, serta memanfaatkan barang daur ulang menjadi berbagai kreasi yang memiliki nilai jual sehingga dapat menambah penghasilan warga. Penggiat bank sampah adalah sekelompok warga yang berinisiatif dan memiliki kepedulian serta tanggung jawab untuk mengatasi sampah dan meningkatkan kualitas lingkungan. Oleh karena itu bank sampah merupakan kegiatan berbasis masyarakat yang menjadi salah satu solusi untuk mengurangi timbulan sampah yang keberadaannya sangat dipengaruhi oleh penggerak, inisiator, dan kontributor yang bersedia menyediakan waktu, tenaga, dan pikiran untuk menjalankan kegiatan bank sampah. Sosialisasi bank sampah dilakukan dengan memberikan edukasi kepada masyarakat akan pentingnya memilah sampah mulai dari tingkat rumah tangga. Kegiatan yang dilakukan oleh bank sampah di Kota Depok antara lain menyediakan fasilitas tabungan sampah anorganik, membuat karya dan pelatihan daur ulang dari bahan sisa kemasan, menyelenggarakan pelatihan manajemen bank sampah, serta melakukan pelatihan pengolahan sampah organik dan anorganik untuk skala rumah tangga. Potensi Timbulan Sampah Anorganik dan Sebaran Bank Sampah dapat dilihat pada Gambar 2. 


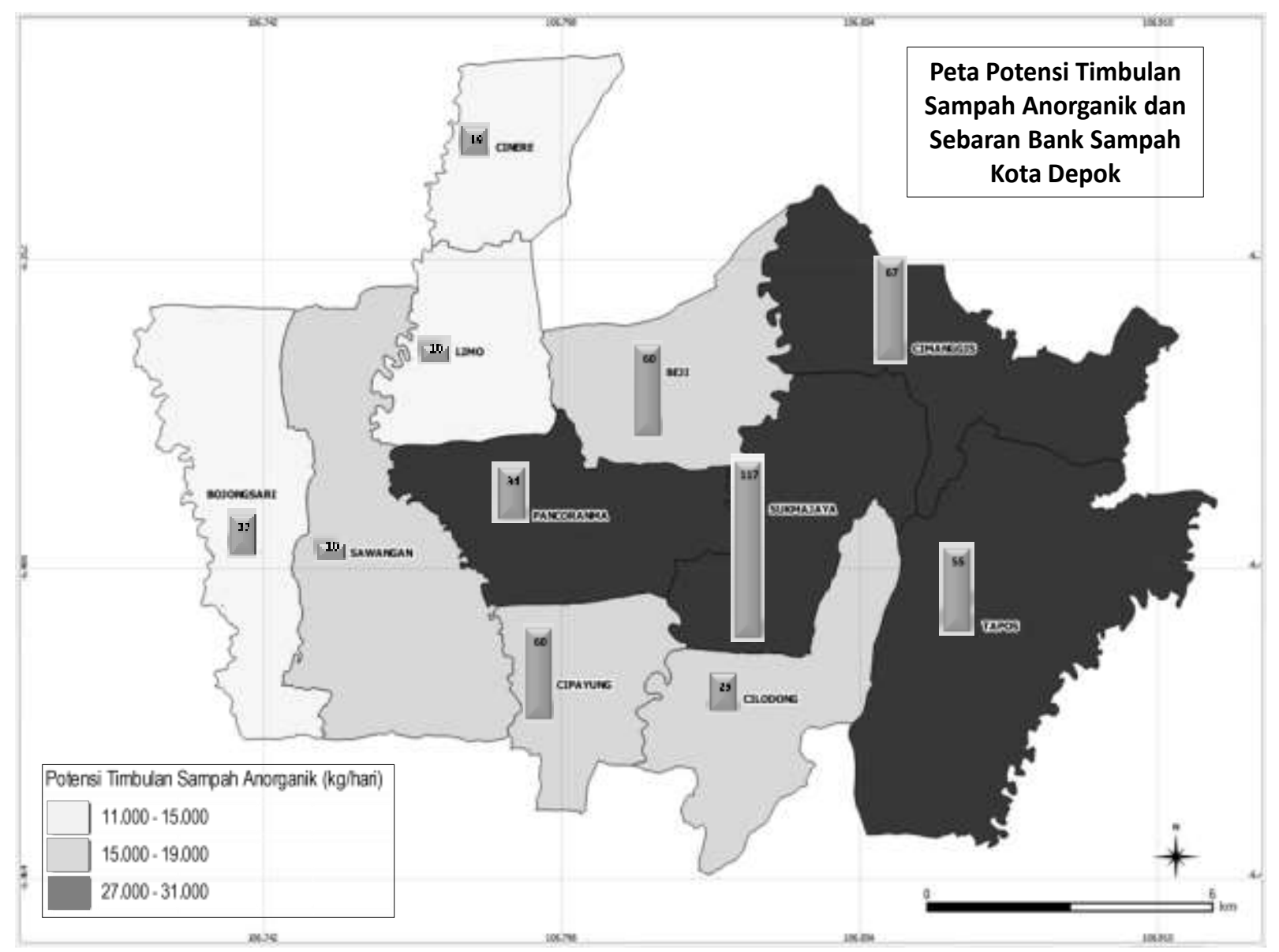

Gambar 2. Peta potensi timbulan sampah anorganik dan sebaran bank sampah Kota Depok Tahun 2016

Mayoritas rumah tangga di Kota Depok belum melakukan pemilahan sampah. Sebagaimana penelitian Environment Health Risk Assessment/EHRA (Pemkot Depok, 2015) bahwa hasil survei menunjukkan jumlah rumah tangga yang melakukan pemilahan sampah sebesar $32.53 \%$. Sisanya sebesar $67.47 \%$ rumah tangga belum melakukan pemilahan sampah. Data ini sejalan dengan data jumlah bank sampah di Kota Depok sebanyak 483 unit yang memberikan kontribusi $20 \%$ terhadap pengurangan sampah anorganik di Kota Depok. Kecamatan Sukmajaya merupakan kecamatan yang paling banyak memberikan kontribusi pada pengurangan sampah di Kota Depok, yaitu sebesar 5\% dengan jumlah bank sampah yang beroperasi sebanyak 117 unit, kemudian Cimanggis sebesar 3\% dengan jumlah bank sampah sebanyak 67 unit, serta Beji dan Cipayung sebesar 2\% dengan jumlah bank sampah sebanyak masing-masing 60 unit. Kecamatan Limo dan Sawangan merupakan kecamatan yang paling sedikit memberikan kontribusi terhadap pengurangan sampah di Kota Depok, yaitu sebesar $0.35 \%$ dengan jumlah bank sampah di kecamatan tersebut masing-masing sebanyak 10 unit. Perbandingan timbulan sampah anorganik dan ketersediaan bank sampah pada setiap kecamatan dapat dilihat dalam bentuk grafik pada Gambar 3 . 


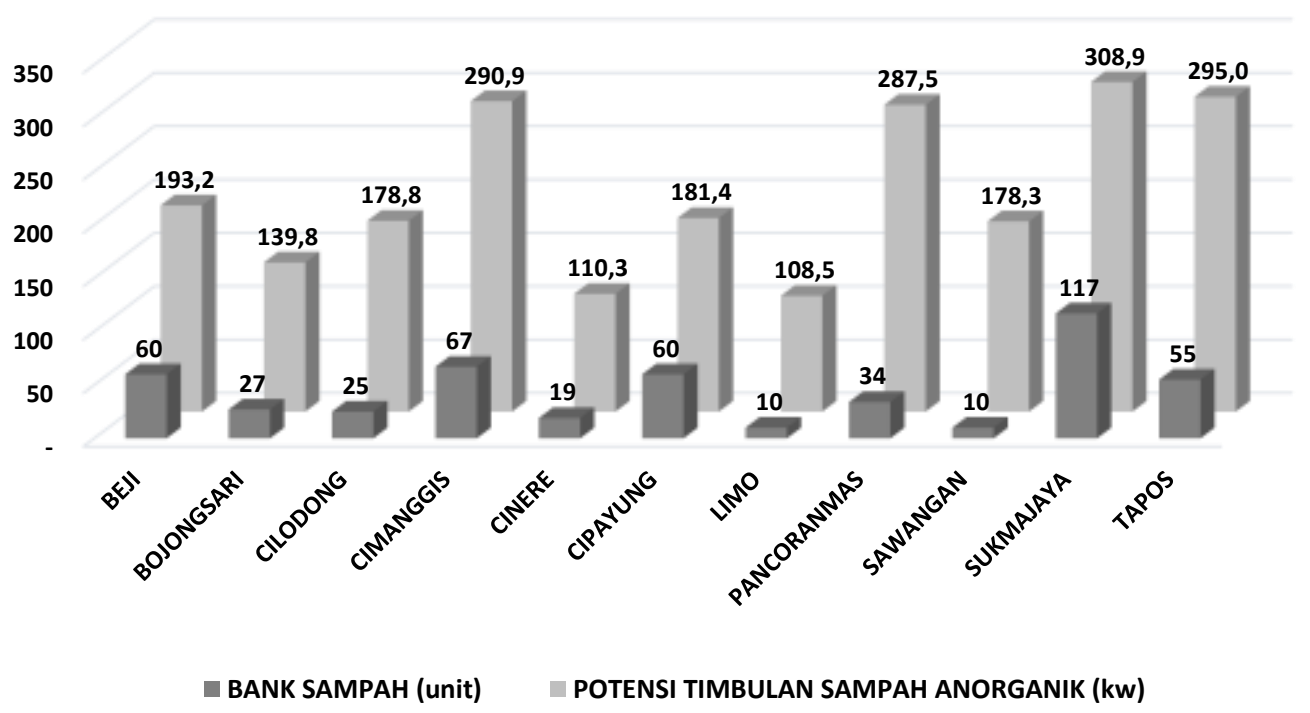

Gambar 3. Grafik Perbandingan Timbulan Sampah Anorganik dan Ketersediaan Bank Sampah pada Setiap Kecamatan di Kota Depok Tahun 2016

Meskipun sistem Bank Sampah memberikan keuntungan berupa pengurangan beban sampah bagi lingkungan dan kesempatan menghasilkan uang dari kerajinan tangan berbahan dasar sampah, namun tidak membuat setiap warga berminat turut berpartisipasi. Bank sampah yang berhasil berkiprah dalam masyarakat umumnya memiliki tenaga sukarelawan dan memperoleh dukungan dari pemimpin wilayah baik ketua RT, RW, maupun lurah.

Keberadaan bank sampah adalah salah satu bentuk keterlibatan warga dalam pengelolaan sampah berupa pemilahan sampah yang berasal dari hulu (sumber sampah). Hal ini sejalan dengan penelitian Heimlich et al. (2007) yang menyatakan bahwa masyarakat perlu memberikan perhatian dan turut berpartisipasi dalam pengelolaan sampah.

Sebagaimana Kota Depok, Kota Malang pun memiliki bank sampah yang berperan dalam mengurangi sampah anorganik yang dihasilkan oleh warga. Menurut Suryani (2014) Bank Sampah Malang merupakan koperasi kerja sama antara pemerintah Kota Malang dan Corporate Social Responsibility (CSR) PT. PLN Distribusi Jawa Timur yang memiliki mekanisme relasi dan jaringan sosial serta peran dropping point bagi produsen untuk produk dan kemasan yang telah usai masa pakainya. Hal ini dapat terlaksana karena pengelolaan Bank Sampah Malang dilakukan secara sistematis dan masif dengan menggerakkan partisipasi masyarakat yang dilengkapi dengan berbagai fasilitas (Sujiyanto, 2016).

Perbedaan antara pengelolaan bank sampah di Kota Depok dan di Kota Malang adalah bank sampah di Kota Depok digerakkan oleh relawan dengan semangat tanggung jawab terhadap lingkungan. Sementara di Kota Malang, pengelolaan bank sampah secara profesional dalam bentuk lembaga koperasi. Oleh karena itu, untuk meningkatkan peran dan kinerja bank sampah di Kota Depok, pengelolaan bank sampah dapat ditingkatkan profesionalitas dan dibangun skema kerja sama dengan pihak swasta.

\section{Analisis Daya Dukung dan Kapasitas Tampung UPS}

Untuk mengatasi permasalahan sampah organik, pemerintah Kota Depok mencanangkan program unggulan Unit Pengolahan Sampah (UPS). UPS dikelola 
dengan memasukan unsur teknologi, sumber daya manusia, sistem, hukum, sosial, dan dana menjadi suatu kenyataan bahwa sampah adalah potensi yang dapat diolah dan dikelola untuk memberikan manfaat bagi masyarakat, bukan sumber masalah. Sampah menjadi sumber daya berupa lapangan kerja serta produk yang bermanfaat dan memiliki nilai jual. Setiap unit UPS terdiri dari kantor, gudang, serta tempat composting, termasuk area pengayakan dan pengemasan dengan luas lahan antara 700 hingga $1000 \mathrm{~m}^{2}$ dan ukuran hanggar sekitar 500 $\mathrm{m}^{2}$ untuk kapasitas pengolahan sampah organik sebanyak 1 sampai 3 ton setiap hari. UPS membutuhkan empat orang tenaga kerja untuk mengolah setiap ton sampah organik per hari. Kegiatan UPS bersifat pelayanan kepada warga karena merupakan fasilitas milik pemerintah Kota. Lokasi UPS tersebar disesuaikan pada ketersediaan lahan sehingga setiap UPS diharapkan mampu melayani sampah organik yang dihasilkan oleh warga Kota Depok dari wilayah mana pun. Potensi timbulan sampah organik dan sebaran UPS di Kota Depok dapat dilihat pada Gambar 4.

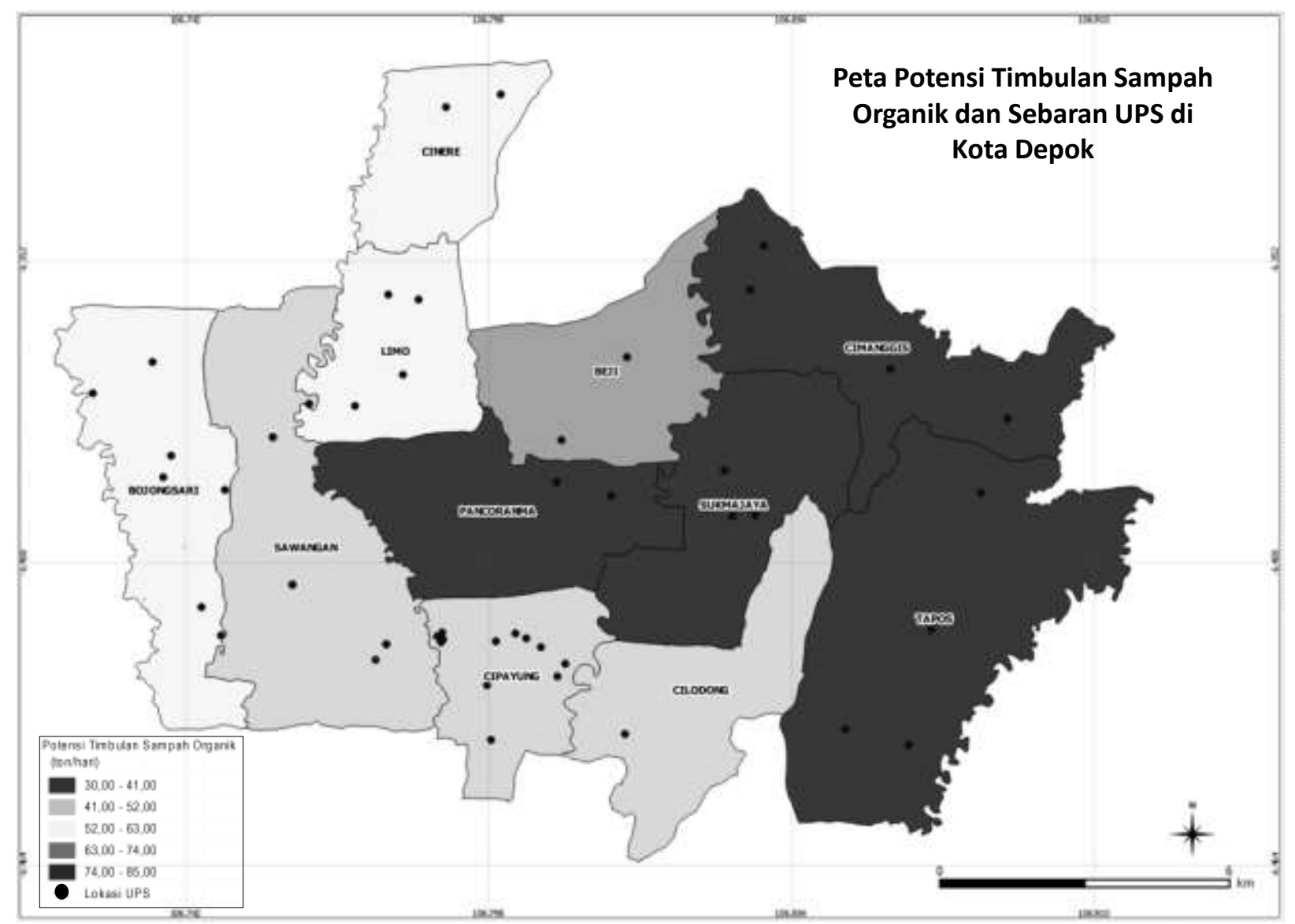

Gambar 4. Potensi timbulan sampah organik dan sebaran UPS di Kota Depok Tahun 2016

Berdasarkan analisis kesesuaian antara potensi timbulan sampah organik dengan ketersediaan prasarana UPS yang terdapat pada setiap kecamatan di Kota Depok, dapat disimpulkan bahwa daya dukung UPS di Kota Depok rendah dengan nilai indeks 0.26 . Kemampuan UPS di Kota Depok telah terlampaui dengan selisih antara kapasitas pengelolaan dan jumlah timbulan sampah organik sebanyak -514.98 ton per hari. Indeks daya dukung dan kapasitas pengelolaan UPS pada setiap kecamatan dapat dilihat pada Tabel 2. 
Tabel 2. Indeks daya dukung dan kapasitas pengelolaan UPS pada setiap kecamatan di Kota Depok Tahun 2016

\begin{tabular}{lllllll}
\hline Kecamatan & $\begin{array}{l}\text { Potensi } \\
\text { Sampah } \\
\text { (ton/hari) }\end{array}$ & $\begin{array}{r}\text { Timbulan } \\
\text { Organik }\end{array}$ & $\begin{array}{l}\text { Jumlah } \\
\text { UPS } \\
\text { (unit) }\end{array}$ & $\begin{array}{l}\text { Kapasitas } \\
\text { UPS } \\
\text { (ton) }\end{array}$ & $\begin{array}{l}\text { Indeks } \\
\text { Daya Dukung } \\
\text { UPS }\end{array}$ & $\begin{array}{l}\text { Kapasitas } \\
\text { Pengelolaan UPS } \\
\text { (ton) }\end{array}$ \\
\hline Beji & 53.14 & 2 & 3.00 & 0.45 & -51.80 \\
Bojongsari & 38.44 & 7 & 21.00 & 0.18 & -17.44 \\
Cilodong & 49.17 & 1 & - & - & - \\
Cimanggis & 79.99 & 4 & 6.00 & 0.19 & -43.17 \\
Cinere & 30.34 & 2 & 3.00 & 0.16 & -27.34 \\
Cipayung & 49.88 & 12 & 28.00 & 0.23 & $-21,88$ \\
Limo & 29.85 & 4 & - & - & - \\
Pancoran Mas & 79.07 & 2 & - & - & - \\
Sawangan & 49.03 & 5 & 6.00 & 0.53 & -43.03 \\
Sukmajaya & 84.94 & 3 & 6.00 & 0.45 & -78.94 \\
Tapos & 81.12 & 4 & 9.00 & 0.43 & -72.12 \\
\hline Kota Depok & 624.98 & 46 & 82.00 & 0.26 & -514.98 \\
\hline
\end{tabular}

Perbandingan antara jumlah potensi timbulan sampah yang dihasilkan warga dengan kapasitas UPS yang tersedia di Kota Depok sangat kecil. Hal ini menyebabkan persentase pengelolaan sampah organik di Kota Depok melalui UPS sangat rendah, yaitu sebesar $3.64 \%$ dari sampah organik yang ada. Walaupun demikian, Dewi (2008) menyatakan bahwa keberadaan UPS bermanfaat dalam pengelolaan sampah di Kota Depok karena memberikan perbaikan dalam pelayanan sampah dan kebersihan lingkungan. UPS juga memiliki manfaat tidak langsung sebagai salah satu sarana edukasi manfaat pengolahan sampah yang secara ekonomis memberikan nilai tambah kepada masyarakat dibandingkan dengan pengelolaan sampah konvensional. Oleh karena itu kinerja UPS perlu terus ditingkatkan.

Pemerintah Kota Depok sebagai penanggung jawab pengelolaan sampah di Kota Depok memiliki peran utama dalam penyediaan dan pengelolaan UPS sebagai prasarana pengelolaan sampah organik. Adanya kesenjangan jumlah UPS dengan jumlah sampah organik yang dihasilkan di setiap kecamatan menunjukkan mendesaknya pemenuhan ketersediaan UPS pada setiap kecamatan oleh pemerintah Kota Depok. Hal ini sejalan dengan penelitian Jati (2013) yang menyatakan bahwa pemerintah daerah merupakan service provider yang berperan dalam menyediakan pelayanan pengelolaan sampah, memberi contoh, dan membuat inovasi pengelolaan sampah. Untuk itu, untuk meningkatkan jumlah sampah organik yang diolah di UPS dalam rangka mengurangi jumlah timbulan sampah organik yang dihasilkan, pemerintah Kota Depok perlu mencukupi kebutuhan UPS di setiap kecamatan.

\section{Analisis Daya Dukung dan Kapasitas Tampung TPA}

Kota Depok memiliki satu unit Tempat Pemrosesan Akhir (TPA) yang terletak di kecamatan Cipayung sebagai satu-satunya lokasi pembuangan akhir sampah Kota Depok. TPA Cipayung memiliki luas 11.2 ha dan telah beroperasi selama sekitar 30 tahun dengan jumlah sampah yang masuk sebanyak 600 ton/hari. Kapasitas TPA sudah maksimal sesuai perencanaan (Pemkot Depok, 2016). Pada tahun 2008 pemerintah Kota Depok telah melakukan perbaikan kondisi TPA berupa dibuatnya tiga kolam penampungan sampah dengan kedalaman masing-masing 7 hingga 10 meter dari permukaan tanah yang dikelola menggunakan sistem sanitary landfill dengan rencana tampung sampah hingga ketinggian 25 hingga 30 meter di atas permukaan tanah.

Pada saat ini ketinggian tumpukan sampah mencapai lebih dari 30 meter karena jumlah yang masuk tidak sebanding dengan luas lahan yang ada menyebabkan TPA Cipayung tidak layak untuk digunakan dan kegiatan pengelolaan sampah tidak efektif. 
Namun demikian, penggunaan TPA Regional Nambo Kabupaten Bogor sebagai pengganti TPA Cipayung baru dapat dilakukan pada tahun 2019. Oleh karena itu dalam pengelolaan sampah Kota Depok saat ini, penggunaan TPA Cipayung dalam bentuk mempertahankan kondisi dengan sistem pembuangan sampah ditumpuk dan dipadatkan. Untuk kelanjutan kegiatan TPA Cipayung, perlu dilakukan evaluasi kualitas lingkungan untuk mengambil keputusan melakukan rehabilitasi atau penutupan TPA secara permanen.

Berdasarkan Lampiran V Peraturan Menteri Pekerjaan Umum Nomor 03/PRT/M/2013 tentang Penyelenggaraan Prasarana dan Sarana Persampahan Dalam Penanganan Sampah Rumah Tangga dan Sampah Sejenis Sampah Rumah Tangga evaluasi kualitas lingkungan dilakukan dengan menggunakan penilaian indeks risiko lingkungan atau Integrated Risk Based Approach (IRBA) (KemenPU, 2013).

Nilai hasil indeks risiko lingkungan TPA Cipayung Kota Depok termasuk dalam kategori 300 sampai dengan 600, yaitu 536.9275 dengan kriteria evaluasi tingkat bahaya sedang dengan rekomendasi tindakan TPA diteruskan dan direhabilitasi menjadi lahan urug terkendali secara bertahap. Hasil penilaian indeks risiko lingkungan TPA Cipayung dapat dilihat pada Tabel 3.

Tabel 3. Hasil penilaian indeks risiko lingkungan TPA Cipayung Kota Depok Tahun 2016

\begin{tabular}{|c|c|c|c|}
\hline TPA & $\begin{array}{l}\text { Nilai } \\
\text { Indeks } \\
\text { Risiko }\end{array}$ & $\begin{array}{l}\text { Evaluasi } \\
\text { Bahaya }\end{array}$ & $\begin{array}{l}\text { Tindakan } \\
\text { yang } \\
\text { Disarankan }\end{array}$ \\
\hline $\begin{array}{l}\text { Cipayung } \\
\text { Kota } \\
\text { Depok }\end{array}$ & 536.9275 & Sedang & $\begin{array}{l}\text { TPA } \\
\text { diteruskan } \\
\text { dan } \\
\text { direhabilitasi } \\
\text { menjadi lahan } \\
\text { urug } \\
\text { terkendali } \\
\text { secara } \\
\text { bertahap }\end{array}$ \\
\hline
\end{tabular}

\section{Penerapan Metode Integrated Risk Based Approach (IRBA) dalam Strategi Rehabilitasi TPA}

Integrated Risk Based Approach (IRBA) merupakan metode yang cocok untuk digunakan dalam melakukan penilaian indeks risiko lingkungan TPA pada negara berkembang. Metode ini mudah diaplikasikan dan terbukti secara ilmiah dapat menunjukkan kualitas TPA. Oleh karena itu metode ini digunakan dalam melakukan evaluasi kualitas lingkungan TPA Eneka di Nigeria dengan hasil TPA memiliki tingkat bahaya sedang. Hasil ini memberikan rekomendasi berupa rehabilitasi TPA perlu segera dilakukan dan mengubah pengelolaan TPA menjadi sistem urug terkendali (Abah \& Ohimain, 2010).

Penilaian indeks risiko lingkungan dengan metode IRBA di Indonesia telah dilakukan oleh Mayangkara (2016) pada TPA Gunung Panggung Kabupaten Tuban dengan hasil evaluasi rekomendasi penerapan sistem sanitary landfill dengan dukungan perbaikan aspek kelembagaan untuk teknis pelaksanaannya. Penelitian Astono et al. (2015) pada TPA Jatiwaringin Kabupaten Tangerang merekomendasikan lahan urug terkendali secara bertahap yang dilakukan dengan pengembangan Zona 4 untuk menunjang kegiatan operasional TPA sebagaimana direncanakan Dinas Kebersihan dan Pertamanan Kabupaten Tangerang.

Dalam alur pilihan aktivitas rehabilitasi TPA berdasarkan nilai indeks risiko, bentuk kegiatan yang dapat dilakukan pada TPA Cipayung adalah penambangan. Hal ini sejalan dengan rencana pengembangan TPA Cipayung. Menurut rencana Penyusunan Masterplan TPA Cipayung Kota Depok Tahun 2015, jika TPA Regional Nambo Kabupaten Bogor sudah dapat digunakan, kegiatan penambangan TPA dapat dilakukan karena beban TPA Cipayung sudah berkurang. Rencana penambangan menggunakan materi sampah yang masih dapat dimanfaatkan, yaitu materi sampah organik dijadikan kompos, sementara materi sampah anorganik akan dikembangkan menjadi Refuse Derived Fuel (RDF). 
Dalam pengelolaan sampah di Kota Depok terdapat kesenjangan antara ketersediaan dan kebutuhan prasarana pelayanan sampah di Kota Depok. Untuk memenuhi pelayanan sampah yang berkeadilan dibutuhkan pemenuhan prasarana persampahan pada setiap wilayah RW dan kelurahan. Kebutuhan dan ketersediaan prasarana pelayanan sampah berdasarkan kategori sampah yang dihasilkan di Kota Depok dapat diketahui pada Tabel 4.

Tabel 4. Kebutuhan dan ketersediaan prasarana pelayanan sampah berdasarkan kategori sampah yang dihasilkan di Kota Depok Tahun 2016

\begin{tabular}{|c|c|c|c|c|c|c|c|}
\hline \multicolumn{3}{|l|}{ Sampah } & \multirow{2}{*}{$\begin{array}{l}\text { Jenis } \\
\text { Prasarana }\end{array}$} & \multicolumn{3}{|c|}{ Prasarana (unit) } & \multirow[t]{2}{*}{ Rekomendasi } \\
\hline Kategori & Jenis & $\begin{array}{l}\text { Jumlah } \\
\text { (ton/hari) }\end{array}$ & & Kebutuhan & Tersedia & Selisih & \\
\hline \multirow[t]{4}{*}{ Organik } & \multirow{4}{*}{$\begin{array}{l}\text { - Daun \& } \\
\text { Ranting } \\
\text { - Sisa } \\
\text { Makanan }\end{array}$} & 193 & UPS & 64 & 30 & -34 & \multirow{4}{*}{$\begin{array}{l}\text { UPS skala Kota } \\
\text { (kapasitas } 100 \text { ton) } \\
1 \text { unit UPS per } \\
\text { kelurahan } \\
\text { (kapasitas } 8 \text { ton) } \\
2 \text { unit budi daya } \\
\text { maggot/kelurahan }\end{array}$} \\
\hline & & \multirow[t]{3}{*}{514} & $\begin{array}{l}\text { (kapasitas } \\
3 \text { ton) }\end{array}$ & 129 & - & -129 & \\
\hline & & & & & & & \\
\hline & & & $\begin{array}{l}\text { Budi daya } \\
\text { Maggot }\end{array}$ & 126 & - & -126 & \\
\hline Anorganik & & 257 & $\begin{array}{l}\text { Bank } \\
\text { Sampah }\end{array}$ & 2572 & 483 & -2089 & $\begin{array}{l}1 \text { unit bank sampah } \\
\text { per } 2 \text { RT }\end{array}$ \\
\hline Residu & & 322 & $\begin{array}{l}\text { Waste to } \\
\text { energy }\end{array}$ & 64 & - & -64 & $\begin{array}{l}1 \text { unit } \\
\text { kelurahan }\end{array}$ \\
\hline
\end{tabular}

Peningkatan pelayanan dan kualitas sistem pengelolaan dibutuhkan agar timbulan sampah yang dihasilkan oleh warga dikelola dengan semestinya. Untuk meningkatkan pelayanan dan kualitas pengelolaan sampah dibutuhkan optimalisasi pemanfaatan sarana dan prasarana persampahan serta peningkatan pelayanan secara terencana dan berkeadilan. Pelayanan pengelolaan sampah harus dapat menjangkau seluruh wilayah, prioritas pelayanan di pusat kota, juga bagi masyarakat kelas ekonomi rendah secara menyeluruh dengan mempertimbangkan kebutuhan dan ketersediaan sumber daya (Handono, 2010).

Pelaksanaan pengelolaan sampah berbasis masyarakat berlandaskan peraturan perundangan yang berlaku dengan memenuhi kebutuhan prasarana pendukung merupakan kunci keberhasilan pengelolaan sampah secara berkelanjutan di Kota Depok. Perencanaan ini baru dapat terlaksana apabila pemerintah Kota Depok selaku penanggung jawab sekaligus pelayan dan regulator dalam pengelolaan perkotaan memberikan perhatian khusus dan prioritas serta mengerahkan segala sumber daya untuk memenuhi kebutuhan pelayanan pengelolaan sampah perkotaan. Hal ini menunjukkan peran strategis pemerintah Kota Depok sebagai penentu keberhasilan pengelolaan sampah berwawasan lingkungan.

\section{KESIMPULAN}

Pemerintah Kota Depok melakukan penanganan sampah berbasis masyarakat melalui 483 unit bank sampah yang mengurangi $20 \%$ potensi timbulan sampah anorganik.

Daya dukung 46 Unit UPS rendah dengan nilai indeks daya dukung sebesar 0.26 dan kapasitas pengelolaan terlampaui, dengan selisih antara kapasitas pengelolaan dan timbulan sampah sebanyak -514.98 ton per hari mampu mereduksi sampah organik sebesar $3.64 \%$.

Hasil penilaian evaluasi kualitas lingkungan TPA Cipayung melalui penilaian indeks risiko lingkungan atau Integrated Risk Based Approach (IRBA) sebesar 536.9275 dengan kategori evaluasi bahaya sedang.

Untuk mencukupi kebutuhan prasarana pengelolaan sampah di Kota Depok dibutuhkan penambahan prasarana bank sampah menjadi 1 unit di setiap RT dan UPS menjadi 1 unit di setiap kelurahan serta penyediaan prasarana 
baru berupa 1 unit UPS skala Kota berkapasitas 100 ton dan budi daya organisme maggot dan prasarana waste to energy pada setiap kelurahan.

\section{DAFTAR PUSTAKA}

Abah, S.O. \& Ohimain, E.I. (2010). Assessment of Dumpsite Rehabilitation Potential Using the Integrated Risk Based Approach : a Case Study of Eneka, Nigeria. World Applied Sciences Journal. 8(4): 436-442

Astono, W., Purwaningrum, P. \& Wahyudyanti, R. (2015). Perencanaan tempat Pembuangan Akhir Sampah dengan menggunakan Metode Sanitary Landfill Studi kasus : Zona 4 TPA Jatiwaringin, Kabupaten Tangerang. Jurnal Teknik Lingkungan. 7(1): 7-16

[BPS] Badan Pusat Statistik. (2017). Persentase Rumah Tangga Menurut Provinsi dan Perlakuan Memilah Sampah Mudah Membusuk dan Tidak Mudah Membusuk, 2013-2014.

www.bps.go.id/linkTabelStatis/view/id/1 360 [14 April 2017].

Dewi, R.S. (2008). Evaluasi Ekonomi dan Sosial Unit Pengolahan Sampah (UPS) Kota Depok. [Skripsi]. Bogor (ID) : Institut Pertanian Bogor

Handono, M. (2010). Model Pengelolaan Tempat Pemrosesan Akhir (TPA) Sampah secara Berkelanjutan di TPA Cipayung Kota Depok-Jawa Barat. Disertasi. Bogor (ID) : Institut Pertanian Bogor

Heimlich, J.E., Kerry, L.H., \& Ann, D.C. (2007). Integrated Solid Waste Management. Extension Factsheet. Ohio (US) : The Ohio State University

Jati, T. K. (2013). Peran Pemerintah Boyolali dalam Pengelolaan Sampah Lingkungan Permukiman Perkotaan. Jurnal Wilayah dan Lingkungan. 1(1) : 1-16
Joshi, R. \& Sirajuddin, A. (2016). Status And Challenges Of Municipal Solid Waste Management In India: A Review. Cogent Environmental Science.2 (1139434) : 118

[KemenLHK] Kementerian Lingkungan Hidup dan Kehutanan. (2015). Rangkaian HLH 2015 - Dialog Penanganan Sampah Plastik. www.menlh.go.id [14 April 2017].

[KemenPU] Kementerian Pekerjaan Umum. (2013). Peraturan Menteri Pekerjaan Umum Republik Indonesia Nomor 03/PRT/M/2013 tentang Penyelenggaraan Prasarana dan Sarana Persampahan dalam Penanganan Sampah rumah Tangga dan Sampah Sejenis Sampah Rumah Tangga. Jakarta (ID): Kementerian PU

Khairunisa, V. (2011). Analisis Daya Dukung Lingkungan Dan Kelayakan Ekonomi Unit Pengolahan Sampah "Mutu Elok" Di Perumahan Cipinang Elok Jakarta Timur. Skripsi. Bogor (ID) : Institut Pertanian Bogor

Kurian, J., Esakku, S., Nagendran, R., \& Visvanathan, C. (2005). A Decision Making Tool for Dumpsite Rehabilitation in Developing Countries. Proceedings of Sardinia 2005, Tenth International Waste Management and Landfill Symposium. Margherita di Pula, Cagliari, Italy: 3-7 October 2005

Mayangkara, A.P. (2016). Evaluasi Kebijakan Pengelolaan Sampah TPA Gunung Panggung Kabupaten Tuban. Jurnal Penelitian Administrasi Publik. 2(2): 427-444

Nguyen, U.N. \& Hans, S. (2009). Sustainable Solutions for Solid Waste Management in Southeast Asian Country. Waste Management. 29(2009):1982-1995

Othman, S.N., Zainura, A.N., Ahmad, H.A., \& Rafiu,O.Y. (2013). Review on Life Cycle Assessment of Integrated Solid Waste Management in Some Asian Countries. Journal of Cleaner Production. 41 : 251262 
Pemerintah Kota Depok. (2016). Laporan Akhir Kajian Teknis Tanah TPA Kota Depok. Depok (ID) : Pemerintah Kota Depok

Pemerintah Kota Depok. (2015). Peraturan Daerah Kota Depok Nomor 1 Tahun 2015 Tentang Rencana Tata Ruang Wilayah (RTRW) Kota Depok Tahun 2012 - 2032. Depok (ID) : Pemerintah Kota Depok

Pravitasari, A.E., Izuru, S., \& Ernan, R. (2016). Towards Resilience of Jabodetabek Megacity: Developing Local Sustainability Index with Considering Local Spatial Interdependency. International Journal Sustainable Future for Human Security, 4(1) : 27-34

Sujiyanto. (2016). Analisis Pengelolaan Sampah di Bank Sampah Malang. Jurnal Ilmu Sosial dan Ilmu Politik. 5(3) : 115122

Suryani, A.S. (2014). Peran Bank Sampah Dalam Efektivitas Pengelolaan Sampah (Studi Kasus Bank Sampah Malang). Aspirasi. 5(1) : 71-84

Tjiptoherijanto, P. (1999). Urbanisasi dan Pengembangan Kota di Indonesia. Populasi. 10(2) : 56-72

Zurbrügg, C. \& Roland, S. (1998). Main Problems and Issues of Municipal Solid Waste Management in Developing Countries with Emphasis of Problems Related to Disposal by Landfill. Third Swedish Landfill Research Symposia. Lulea (SE) : SANDEC/EAWAG 